\section{Use of Herbicides and Plant Growth Regulators to Suppress Italian Ryegrass Growth}

\author{
C.L. Gupton ${ }^{1}$
}

Additional index wORds. living mulch, Lolium multiflorum, plant growth suppression, mefluidide, sethoxydim, triclopyr

Summary. Several concentrations of mefluidide (E mbark), a plant growth regulator; sethoxydim (Poast), a grass herbicide; and triclopyr (R ely) a nonselective herbicide, were evaluated to determine if italian ryegrass (Lolium multiflorum L am.) growth could be suppressed. $R$ yegrass grows prolifically during the winter in states adjacent to the $\mathbf{G}$ ulf of M exico and may serve as a living mulch for strawberry (Fragaria xananasa D uch.) and other winter crops if its growth can be controlled. $D$ ifferent chemicals and concentrations were screened over 5 years for their efficacy to produce living mulch. M efluidide produced good ryegrass control but was not evaluated after Study 1 because it is designed for industrial use and does not have an U.S. Environmental Protection Agency fruit crop label. T riclopyr, which has a label for several fruit crops, was studied only in the final year and it provided desired ryegrass control at the 0.016 and $0.030 \mathrm{~mL}^{-1} \mathrm{~L}^{-1}$ (parts per thousand) rate. Prime oil (paraffin base petroleum oil + polyol fatty acid esters) concentration affected results when sprayed with various sethoxydim rates. We concluded that $0.156 \mathrm{~mL} \cdot \mathrm{L}^{-1}$ sethoxydim plus 0.25 $\mathrm{mL} \cdot \mathrm{L}^{-1}$ prime oil will control ryegrass growth at the desired level (reduce growth by $40 \%$ to $50 \%$ ) for living mulch. These rates are too low to

The author thanks Bryan Vineyard and Blair Sampson for assistance in statistical analyses. $M$ ention of a trademark, proprietary product, or vendor does not constitute a guarantee or warranty of the product by the U SD A and does not imply its approval to the exclusion of other products or vendors that also may be suitable. The cost of publishing this paper was defrayed in part by the payment of page charges. U nder postal regulations, this paper therefore must be hereby marked advertisement solely to indicate this fact.

${ }^{1}$ Research geneticist, U SD A-ARS Small F ruit R esearch Station, P.O. Box 287, Poplarville, M S 39470. cause much ryegrass browning. Chemical names used: $\mathrm{N}-[2,4 \mathrm{dim}$ ethyl-5-[[(trifluoromethyl)sulfony]amino] phenyl] acetamide, 2[1-(ethoxylmino)buty1]-5-[2(ethylthio)propy1]-3-hydroxy-2cyclohexen-1-one), and ammoniumDl-homoalanin-4-yl-(methyl) phosphinate.

$n$ the coastal plain soils of states adjacent to the Gulf of M exico, living mulch may beuseful in a strawberry or winter vegetable plasticulture system to reduce soil erosion, control winter weeds, and provide a clean picking area. M ethodology for producing living mulch is needed for evaluation on strawberry and possibly other winter crops. Living mulch can reduce soil erosion, aid in maintaining soil structure, and reduce bed degradation (Roe et al., 1994).

Living mulch has been evaluated for sweet corn (Zea maysL.) and cabbage (Brassi ca oleracea L . var. Capitata) ( $N$ icholson and Wien, 1983), bell pepper (C apsicum annuum L.) and squash (C ucurbi ta pepoL.) (Roe et al., 1994), broccoli (Brassica oleracea L. var. italica) (C astello, 1994), and field corn (Zea mays L.) (Elkins et al., 1979) production systems. $\mathrm{N}$ icholson and Wien (1983) and Roe et al. (1994) screened grasses and legumes for use as living mulch that did not stress sweet corn, cabbage, bell pepper, and squash. Attemptsat intercropping with living mulches have been successful with (Elkins et al., 1979) and without (Infante and M orse, 1996) chemical suppression of the living mulch to prevent excessive competition with the crop. Grubinger and M inotti (1990) controlled white clover (Trifolium repens L.) mulch with partial rototilling. Because winter fruit and vegetable cropsmay be protected from competition with living mulch by polypropylene mulch on a bed, chemical suppression is usually needed only to contain ryegrass growth within furrows.

I talian ryegrass has the potential to serve as living mulch if its growth can be controlled. Sublethal concentrations of chemicals are needed to suppress ryegrass growth. Several concentrations of mefluidide, a plant growth regulator; sethoxydim, a grass herbicide; and triclopyr, anonselective herbicide, were evaluated 1993-96.
The objective of this study was to determine asuitable sublethal concentration of each chemical to reduce ryegrass growth by an estimated $40 \%$ to $50 \%$

\section{Materials and methods}

Study 1 (1992-93). To obtain a thick, uniform stand, italian ryegrass was broadcast on $200 \mathrm{ct} .1992$ at 57 $\mathrm{kg} \cdot \mathrm{ha}^{-1}(50 \mathrm{lb} / \mathrm{acre})$ on a0.11-ha(0.27acre) plot. Before seeding, $800 \mathrm{~kg} \cdot \mathrm{ha}^{-1}$ (700 lb/ acre) fertilizer (13N -6P-11K) was broadcast and tilled into a R uston fine sandy loam soil (fine-loamy, siliceous, Thermic Typic paleudult). I rrigation was applied only after seeding to promote uniform germination. R yegrass for all future studies was established by the same procedure. All studies were conducted at the Small Fruit Research Station, Poplarville, $\mathrm{M}$ iss.

O n 22 J an. 1993, five sethoxydim (Poast; BASF Corp., Research Triangle Park, N.C.) treatments $(8,6,4$, 2 , and $1 \mathrm{~mL} \cdot \mathrm{L}^{-1}$ ) plus $8 \mathrm{~mL} \cdot \mathrm{L}^{-1}$ prime oil (PO) (Riverside/ TerraC orp. Sioux City, lowa) as a spreader-sticker in each treatment, five mefluidide ( $\mathrm{Em}$ bark; pbi/ G ordon C orp., KansasC ity, Kans.) treatments $(0.0030,0.0022$, $0.0015,0.0011$, and $\left.0.0004 \mathrm{~mL} \cdot \mathrm{L}^{-1}\right)$, and an untreated control were included in each of three replications. When the ryegrass was about $15 \mathrm{~cm}$ ( 6 inches) tall, the plots were misted but not wet to runoff using a high pressure backpack sprayer with ano. 3 flat fan nozzle at $2.1 \mathrm{~g} \cdot \mathrm{cm}^{-2}\left(30 \mathrm{lb} /\right.$ inch $\left.^{2}\right)$. Plots $1 \times 6$ $\mathrm{m}(3.3 \times 19.7 \mathrm{ft})$ with $1.2 \mathrm{~m}(4 \mathrm{ft})$ borders between plots to protect from drift were arranged in a randomized complete block design. R yegrass from the mefluidide treated plots was harvested by replication with a $61 \mathrm{~cm} \mathrm{(2}$ $\mathrm{ft}$ ) wide sickle mower between 6 and $14 \mathrm{M}$ ay 1993 . Fresh weight $\left(\mathrm{kg} \cdot \mathrm{m}^{-2}\right)$ of ryegrass from each plot was determined. The regression of weight on treatment level was computed by an asymptotic regression model, $Y=a-b$ $\exp (-c X)$ where $b=Y$ intercept, $\alpha=$ asymptote, and $c=$ the rate at which $y$ changesfrom itsinitial value to itsfinal value (Ratkowsky, 1983). An F test comparing lack of fit sums of squares was not statistically different from the pure error sums of squares at $\alpha=0.05$. Bates and Watts, 1988). H ence, the asymptotic regression model provides a good fit to the data.

Study 2 (1995). O n 24 J an. 1995 


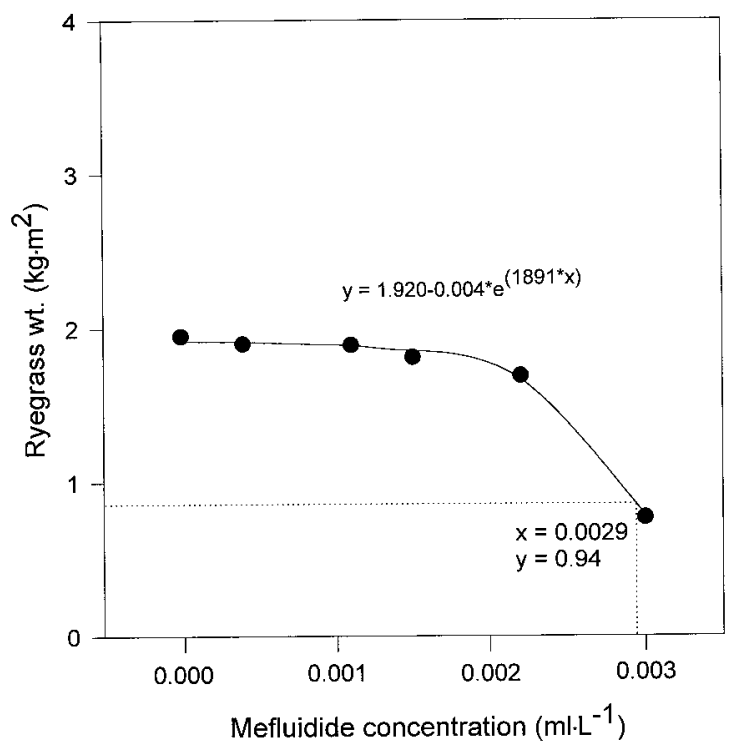

Fig. 1. Asymptotic regression of ryegrass fresh weight on mefluidide ( $\mathrm{mL} \cdot \mathrm{L}^{-1}=$ parts per thousand) concentration in 1993. Fit of the equation to the actual data is not statistically different at $\alpha=0.05$.

sethoxydim was applied to ryegrass planted between strawberry seedling rows when they wereestablished during 0 ct 1994. Plots $30.5 \mathrm{~m}$ (100 ft) long were delineated in a randomized complete block design with two replications. Sethoxydim at four concentrations $\left(0.50,0.25,0.06\right.$, and $\left.0 \mathrm{~mL} \cdot \mathrm{L}^{-1}\right)$ in all possible combinations with $\mathrm{PO}$ at three levels $(0.06,0.13$, and 0.25 $\mathrm{mL} \cdot \mathrm{L}^{-1}$ ) were applied. Plots were rated $2 \mathrm{M}$ ar. 1995 using the following scale: 1) normal ryegrass growth; 2) slight growth suppression and some ryegrass browning; 3) medium growth suppression and medium amount of ryegrassbrowning; 4) medium growth suppression and large amount of ryegrass browning; 5) most of the ryegrass brown; and 6) all ryegrass dead. The data were analyzed by general linear models procedure (SAS I nstitute, Inc.; ( ary N C). M eans were separated by $D$ uncan's multiple range test $(P \leq 0.05)$.

StudY 3 (1995-96). A 0.05-ha (0.124-acre) ryegrass plot was seeded 120 ct. 1995. Plots $1 \times 3 \mathrm{~m}(3.3 \times 9.8$ $\mathrm{ft}$ ) in size were delineated so that seven treatments were arranged in a randomized complete block with four replications. Plots were separated by a 1-m (3.3-ft) border on all sides. We suspected that the usual PO level wascausing browning when used with reduced sethoxydim rates. Sethoxydim and PO were applied $13 \mathrm{~N}$ ov. 1995 in the following combinations: 0 sethoxydim plus 0 and $0.25 \mathrm{~mL} \cdot \mathrm{L}^{-1} \mathrm{PO}, 0.06$ $\mathrm{mL} \cdot \mathrm{L}^{-1}$ sethoxydim plus 0.13 $\mathrm{mL} \cdot \mathrm{L}^{-1} \mathrm{PO}, 0.25 \mathrm{~mL} \cdot \mathrm{L}^{-1}$ sethoxydim plus 0.13 and $0.25 \mathrm{~mL} \cdot \mathrm{L}^{-1} \mathrm{PO}$, and 0.50 $\mathrm{mL} \cdot \mathrm{L}^{-1}$ sethoxydim plus 0.06 and $0.13 \mathrm{~mL} \cdot \mathrm{L}^{-1} \mathrm{PO}$. Plots were rated 5 Feb. 1996 using the above scale and the data were analyzed as in the J anuary 1995 sethoxydim treatments.

STUdY 4 (1996). R yegrass was again seeded in the 0.05 ha plot 10 ct. 1996. Experimental units consisted of 1 $\mathrm{m}^{2}$ test plots with 1-m-wide borders on all sides. Seven levels of triclopyr (Rely; H oechst-Roussel, Wilmington, Del.), six sethoxydimPO combinations, and an untreated control were applied in a randomized complete block design with four replications. T reatments consisted of 0.500 , $0.250,0.125,0.062,0.030,0.016$, and $0.008 \mathrm{~mL} \cdot \mathrm{L}^{-1}$ triclopyr; 0 sethoxydim plus $0.5 \mathrm{~mL} \cdot \mathrm{L}^{-1} \mathrm{PO} ; 0.06$ $\mathrm{mL} \cdot \mathrm{L}^{-1}$ sethoxydim plus $0.25 \mathrm{~mL} \cdot \mathrm{L}^{-1}$ PO; $0.25 \mathrm{~mL} \cdot \mathrm{L}^{-1}$ sethoxydim plus 0.25 and $0.50 \mathrm{~mL} \cdot \mathrm{L}^{-1} \mathrm{PO}, 0.50 \mathrm{~mL} \cdot \mathrm{L}^{-1}$ sethoxydim plus 0.08 and $0.25 \mathrm{~mL} \cdot \mathrm{L}^{-1}$ PO; and an untreated control. The treatmentswere applied $13 \mathrm{~N}$ ov. 1996 and the plots were rated $16 \mathrm{D} \mathrm{ec} .1996$ and analyzed as in the previous two experiments. The asymptotic regression of rating on sethoxydim concentration at $0.25 \mathrm{~mL} \cdot \mathrm{L}^{-1} \mathrm{PO}$ and on

Table 1. Effects of four sethoxydim and three prime oil (paraffin-base petroleum oil + polyol fatty acid esters) concentrations on ryegrass suppression in strawberry seedling furrows when treated $24 \mathrm{~J}$ an. 1995 and rated 2 M ar. 1995.

\begin{tabular}{lcc}
\hline & Treatment & \\
\hline $\begin{array}{l}\text { Sethoxydim } \\
\left(\mathbf{m L} \cdot \mathbf{L}^{-1}\right)^{\mathbf{z}}\end{array}$ & $\begin{array}{c}\text { Prime oil } \\
\left(\mathbf{m L} \cdot \mathbf{L}^{-1}\right)\end{array}$ & R ating \\
\hline 0.50 & 0.25 & $6.0 \mathrm{a}^{\mathbf{x}}$ \\
0.50 & 0.13 & $5.0 \mathrm{~b}$ \\
0.50 & 0.06 & $4.0 \mathrm{~b}$ \\
0.25 & 0.25 & $4.0 \mathrm{~b}$ \\
0.25 & 0.13 & $4.0 \mathrm{~b}$ \\
0.25 & 0.06 & $2.5 \mathrm{C}$ \\
0.06 & 0.25 & $2.5 \mathrm{C}$ \\
0.06 & 0.13 & $2.5 \mathrm{C}$ \\
0.06 & 0.06 & $1.5 \mathrm{~cd}$ \\
0 & 0.25 & $1.5 \mathrm{~cd}$ \\
0 & 0.13 & $1.0 \mathrm{~d}$ \\
0 & 0.06 & $1.0 \mathrm{~d}$ \\
\hline
\end{tabular}

zParts per thousand.

YRating from 1 to 6 where $1=$ normal ryegrass growth and $6=$ ryegrass dead ( 3 rating is desired)

$\times M$ eans followed by the same letter do not differ significantly by $D$ uncan's multiple range test at $P \leq 0.05$.

Table 2. E ffects of four sethoxydim and variable prime oil (paraffin-base petroleum oil + polyol fatty acid esters)concentrations on ryegrass growth suppression when treated $13 \mathrm{~N}$ ov. 1995 and rated 5 F eb. 1996.

\begin{tabular}{lcc}
\hline $\begin{array}{l}\text { Sethoxydim } \\
\left(\mathbf{m L} \cdot \mathbf{L}^{-1}\right)^{\mathbf{z}}\end{array}$ & Treatment & \\
\hline 0.25 & $\begin{array}{c}\text { Prime oil } \\
\left(\mathbf{m L} \cdot \mathbf{L}^{-1}\right)\end{array}$ & R ating $^{\mathbf{y}}$ \\
0.25 & 0.13 & $6.0 \mathrm{a}^{\mathrm{x}}$ \\
0.50 & 0.25 & $5.2 \mathrm{a}$ \\
0.50 & 0.06 & $5.2 \mathrm{a}$ \\
0.06 & 0.13 & $3.7 \mathrm{~b}$ \\
0 & 0.13 & $2.5 \mathrm{C}$ \\
0 & 0.25 & $1.0 \mathrm{~d}$ \\
\hline
\end{tabular}

zParts per thousand.

YRating from 1 to 6 where $1=$ normal ryegrass growth and $6=\operatorname{grass}$ dead (a 3 rating is desired).

${ }^{x} M$ eans followed by the same letter do not differ significantly by $D$ uncan's multiple range test at $P \leq 0.05$. 


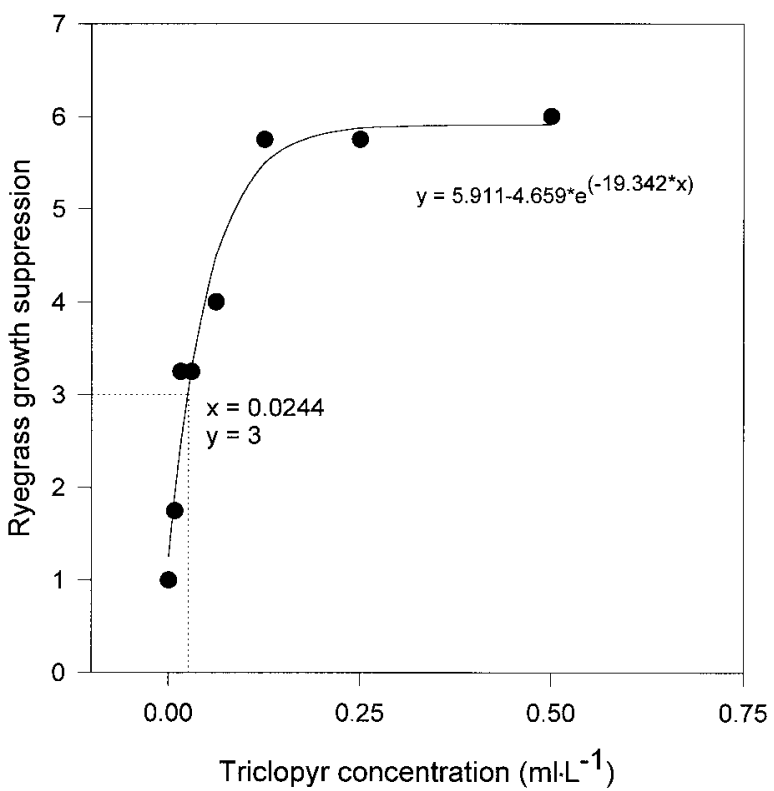

Fig. 2. Asymptotic regression of ryegrass growth suppression on triclopyr $\left(\mathrm{mL} \cdot \mathrm{L}^{-1}=\right.$ parts per thousand) concentration in 1996. Fit of the equation to the actual data is not statistically different at $\alpha=0.05$.

triclopyr were computed as for the 1993 mefluidide data. I n each instance the regression model provided a good fit to the databy the $F$ test described in Study 1.

\section{Results and discussion}

Study 1 (1992-93). Sethoxydim at all rates was lethal to the ryegrass in 1993 (data not shown). A significant quadratic response of reduced plant growth to increased mefluidide concentration occurred (Fig. 1). $M$ efluidide regulated ryegrass growth sufficiently for living mulch purposes at $0.0030 \mathrm{~mL} \cdot \mathrm{L}^{-1}$, which isclose to the concentrations predicted by the regression curve(Fig. 1). Thistreatment produced about $40 \%$ of thefresh weight of untreated ryegrass. M efluidide was not evaluated further because it is unlikely to be labeled for use on fruit crops. It is a growth regulator used to reduce the frequency of mowing and trimming in public, commercial, and industrial areas.

STUDY 2 (1995). PO at afraction of the usual spray concentration used with sethoxydim to kill grass $\left(8 \mathrm{~mL} \cdot \mathrm{L}^{-1}\right)$ resulted in ryegrass browning in strawberry seedling rowsin 1995 (T able 1). $\mathrm{H}$ igher PO concentrations generally produced more ryegrass browning at the same sethoxydim level. All 0.50 and the $0.25 \mathrm{~mL} \cdot \mathrm{L}^{-1}$ sethoxydim with
0.13 and $0.25 \mathrm{~mL} \cdot \mathrm{L}^{-1} \mathrm{PO}$ resulted in unacceptable ryegrass browning. O ptimum ryegrasscontrol (close to 3 rating) was produced by the $0.25 \mathrm{~mL} \cdot \mathrm{L}^{-1}$ sethoxydim with 0.06 $\mathrm{mL} \cdot \mathrm{L}^{-1} \mathrm{PO}$ and $0.06 \mathrm{~mL} \cdot \mathrm{L}$ ${ }^{1}$ sethoxydim with 0.13 or $0.25 \mathrm{~mL} \cdot \mathrm{L}^{-1} \mathrm{PO}$. N 0 browning wasproduced by PO alone.

Study 3 (1995-96). The sethoxydim plus PO treatment combinations were inconsistent in their effect on ryegrass growth in 1995-96 (Table 2). The $0.50 \mathrm{~mL} \cdot \mathrm{L}^{-1}$ sethoxydim treatment rated significantly better than the 0.25 $\mathrm{mL} \cdot \mathrm{L}^{-1}$ treatment at $0.13 \mathrm{~mL} \cdot \mathrm{L}^{-1} \mathrm{PO}$. This discrepancy could have been caused by an error in application. The $0.25 \mathrm{~mL} \cdot \mathrm{L}^{-1} \mathrm{PO}$ treatment alone produced no effect on ryegrass growth. D esirable growth suppression was accomplished by $0.06 \mathrm{~mL} \cdot \mathrm{L}^{-1}$ sethoxydim plus $0.13 \mathrm{~mL} \cdot \mathrm{L}^{-1} \mathrm{PO}$ treatment.

Study 4 (1996). In 1996, triclopyr produced a significant quadratic effect on ryegrass growth suppression with increased rates between 0 and 0.50 $\mathrm{mL} \cdot \mathrm{L}^{-1}$ (Fig. 2). The mean rating for untreated ryegrass was 1.0 and that for the $0.50 \mathrm{~mL} \cdot \mathrm{L}^{-1}$ triclopyr concentration was 6.0 (Table3). T riclopyr at the
0.016 and $0.030 \mathrm{~mL} \cdot \mathrm{L}^{-1}$ concentrations provided desired ryegrass growth control (3 rating). Theprediction curve was in close agreement with actual growth suppression (Fig. 3). The predicted optimum concentration was $0.024 \mathrm{~mL} \cdot \mathrm{L}^{-1}$.

At the same level of sethoxydim, PO concentration did not make a significant difference in ryegrass growth (Table 3), but PO alone at the 0.50 $\mathrm{mL} \cdot \mathrm{L}^{-1}$ level increased browning and significantly reduced plant growth. The prediction curveindicates that themost desirable growth suppression is produced by $0.156 \mathrm{~mL} \cdot \mathrm{L}^{-1}$ sethoxydim plus $0.25 \mathrm{~mL} \cdot \mathrm{L}^{-1} \mathrm{PO}$ (Fig. 3). Thisisa much lower rate than that used by Bush et al. (1998) to suppress seedhead formation and height in carpetgrass (Axonopus affinis Chase). At the time ryegrass is treated to produce living mulch it is much more succulent than carpetgrass at seedhead formation and it probably requires a lower rate of sethoxydim than the latter.

Several concentrations of sethoxydim wasfound in the course of thestudiesto suppressryegrassgrowth sufficiently to produce living mulch. $\mathrm{N}$ one differed much from the prediction of $0.156 \mathrm{~mL} \cdot \mathrm{L}^{-1}$ sethoxydim plus $0.25 \mathrm{~mL} \cdot \mathrm{L}^{-1} \mathrm{PO}$ in Study 4. Triclopyr produced suitable living mulch at two concentrations. I is labeled for use on some fruit crops but not on strawberry. M efluidide also produced suit-

Table 3. Effects of spraying ryegrass planted $10 \mathrm{ct} 1996$ with various triclopyr herbicide rates and various combinations of sethoxydim and prime oil (paraffin-base petroleum oil + polyol fatty acid esters) levels applied on $13 \mathrm{~N}$ ov. 1996 and rated on $16 \mathrm{Dec} .1996$.

\begin{tabular}{lccc}
\hline & \multicolumn{2}{c}{ Treatment } & \\
\cline { 2 - 3 } H erbicide & $\begin{array}{c}\text { Herbicide } \\
\left(\mathbf{m L} \cdot \mathbf{L}^{-\mathbf{1}} \mathbf{z}^{\mathbf{2}}\right.\end{array}$ & $\begin{array}{c}\text { Prime oil } \\
\left(\mathbf{m L} \cdot \mathbf{L}^{-1} \mathbf{)}\right.\end{array}$ & R ating \\
\hline Triclopyr & 0.500 & 0 & $6.0 \mathrm{a}^{\mathrm{x}}$ \\
Triclopyr & 0.250 & 0 & $5.7 \mathrm{ab}$ \\
Triclopyr & 0.125 & 0 & $5.7 \mathrm{ab}$ \\
Sethoxydim & 0.500 & 0.08 & $4.5 \mathrm{bc}$ \\
Sethoxydim & 0.500 & 0.25 & $4.2 \mathrm{~cd}$ \\
Triclopyr & 0.062 & 0 & $4.0 \mathrm{~cd}$ \\
Sethoxydim & 0.250 & 0.50 & $4.0 \mathrm{~cd}$ \\
Sethoxydim & 0.250 & 0.25 & $3.5 \mathrm{~cd}$ \\
Triclopyr & 0.030 & 0 & $3.2 \mathrm{cde}$ \\
Triclopyr & 0.016 & 0 & $3.2 \mathrm{cde}$ \\
Sethoxydim & 0 & 0.50 & $3.2 \mathrm{cde}$ \\
Sethoxydim & 0.060 & 0.25 & $2.7 \mathrm{de}$ \\
Triclopyr & 0.008 & 0 & $1.7 \mathrm{ef}$ \\
Sethoxydim & 0 & 0 & $1.0 \mathrm{f}$ \\
\hline
\end{tabular}

zParts per thousand.

YRating from 1 to 6 where $1=$ normal ryegrass growth and $6=$ ryegrass dead (a 3 rating is desired).

${ }^{x} \mathrm{M}$ eans followed by the same letter do not differ significantly by $D$ uncan's multiple range test at $P \leq 0.05$. 


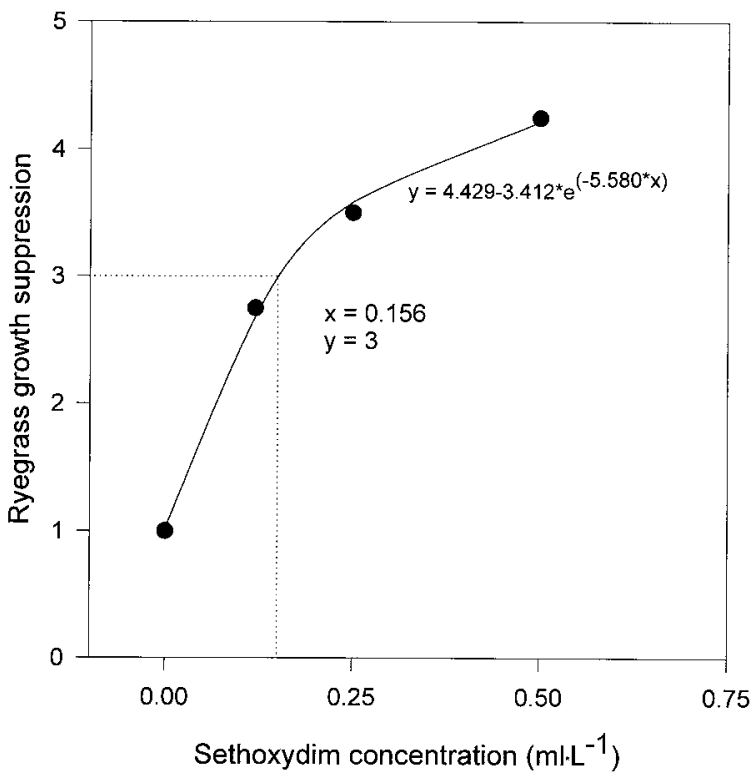

linear regression analysis and its applications. John Wiley, N ew York.

Bush, E.W., W.C. Porter, D.R. Shepard, and J.N. M cCrimmon. 1998. Controlling growth of common carpetgrassusing selected plant growth regulators. HortScience 33:704-706.

Castello, M.J. 1994. Broccoli growth, yield, and level of applied infestations in leguminousliving mulches. Biol. Agr. H ort. 10:207-222.

Elkins, D.M., J.W. Vandeventer, G. Kapusta, and M.R. Anderson. 1979. Notillage maize production in chemically suppressed grass sod. Agron. J. 71:101-105.

Fig. 3. Asymptotic regression of ryegrass growth suppression on sethoxydim concentration at the $\mathbf{0 . 2 5}$ $\mathrm{mL} \cdot \mathrm{L}^{-1}$ (parts per thousand) prime oil (paraffin base petroleum oil + polyol fatty acid esters) concentration in 1996. Fit of the equation to the actual data is not statistically different at $\alpha=0.05$.

able growth control but obtaining a label for use on strawberry and winter vegetable crops may be difficult. We concluded that the best rate of sethoxydim $\left(0.156 \mathrm{~mL} \cdot \mathrm{L}^{-1}\right)$ plus PO $\left(0.25 \mathrm{~mL} \cdot \mathrm{L}^{-1}\right)$ predicted by the curve in Fig. 3 would provide the most suitable living mulch at the present time.

\section{Literature cited}

Bates, D.M . and D.G. Watts. 1988. N on-
Grubinger, V.P. and P.L. M inotti. 1990. $M$ anaging white clover living mulch for sweet corn production with partial rototilling. Amer. J. Alternative Agr. 5:4-12.

Infante, M.L. and R.D. M orse. 1996. Integration of no tillage and overseeded legumeliving mulchesfor transplanted broccoli production. H ortScience 31:376-380.

Nicholson, A.G. and H.C. Wien. 1983. Screening of turf grasses and cloversfor use as living mulches in sweet corn and cabbage. J. Amer. Soc. H ort. Sci. 108:10711076.

Ratkowsky, D.A. 1983. N onlinear regression modeling-A unified practical approach. M arcel D ekker, N ew York.

Roe, N .E., P.J. Stoffella, and H .H . Bryan. 1994. Growth and yields of bell pepper and winter squash grown with organic and living mulches. J. Amer. Soc. H ort. Sci. 119:1193-1199. 